\title{
LA OBRA LITERARIA DE BRUCE CHATWIN: DISQUISICIONES ENTORNO A SU CLASIFICACIÓN
}

\author{
Isabel López Hernández, Universidad Politécnica de Madrid \\ E-mail: isabel.lopez@upm.es
}

\begin{abstract}
Resumen: El escritor británico Bruce Chatwin (1940-1989) creó su obra literaria a partir de la indagación filosófica sintetizada en la pregunta ¿por qué viaja el hombre en lugar de quedarse en casa? Ni su trayectoria vital ni su producción intelectual pueden entenderse sin tener presente ese interrogante que le caracterizó y que cuestionó la clasificación de su obra. El presente artículo se propone situar a Chatwin dentro del género de la literatura de viajes y explicar las raíces de su vocación literaria a través de sus motivaciones y la evolución de la literatura de viajes en el siglo XX.
\end{abstract}

Palabras clave: Bruce Chatwin, literatura de viajes, homo viator, horreur du domicile, Sociedad Geográfica Británica, Blaise Pascal, Baudelaire.

\begin{abstract}
The British writer Bruce Chatwin (1940-1989) built his literary work taking as a starting point the philosophical inquiry summarized in the question: why do men travel instead of staying at home? Neither his life neither his literary career can be understood without taking into consideration this interrogation that characterized him and that questioned the classification of his books. This article intends to place Chatwin's work in the genre of travel literature and explain the roots of his literary yearning throughout his motives and the evolution of travel literature throughout the $20^{\text {th }}$ century.

Keywords: Bruce Chatwin, travel literature, homo viator, horreur du domicile, Royal Geographical Society, Blaise Pascal, Baudelaire.
\end{abstract}

\section{INTRODUCCIÓN}

Todas las obras del escritor británico Bruce Chatwin constituyen una anatomía de la inquietud, como él denominó en una ocasión al análisis minucioso del instinto viajero del hombre. Inventó este concepto para glosar el dicho de Blaise Pascal, según el cual la infelicidad procedía de la incapacidad humana de permanecer en una habitación sentados. No se puede afrontar la idea de la mortalidad y por ello se buscan constantemente distracciones que desvíen la atención sobre la única preocupación: la muerte (Pascal 1998: 78). De esta forma, el hombre está condenado a cambiar de lugar constantemente con el único fin de evitar la pregunta existencial. Chatwin padecía las consecuencias de lo que Baudelaire denominaba "horreur du domicile", el terror a permanecer en casa (Baudelaire 2010: 12). 
Dedicó su vida a investigar las raíces del problema preguntándose: ¿Por qué viaja el hombre en lugar de quedarse en su hogar?

Ni su vida ni su obra pueden comprenderse sin tener presente este interrogante. Cada una de sus creaciones tratan de una u otra manera sobre el desasosiego humano. Constituyen un estudio de la anatomía de la inquietud. Al final del camino esa inquietud se tradujo en una obra literaria compleja y única compuesta por cinco obras: En la Patagonia; El Virrey de Ouidah; Colina Negra; Los trazos de la canción, y Utz. A través de ellos, se planteó ese enigma e indagó acerca de la verdadera naturaleza del alma viajera. Analizó en estos libros el espíritu nómada que le impulsaba a emprender el camino convirtiéndose finalmente en uno de los escritores más originales del pasado siglo. Su inquietud le transformó en un viajero literario herido por la nostalgia de un pasado nómada.

\section{LA OBRA LITERARIA DE BRUCE CHATWIN: ANATOMÍA DE UNA INQUIETUD}

Bruce Chatwin sentía tal pasión por el tema de los nómadas que llegó a escribir el primer capítulo de un libro que nunca terminaría: La alternativa nómada. Trabajó durante tres años en el manuscrito y estaba a punto de abandonarlo cuando el editor del Sunday Times en Londres le ofreció un puesto en la revista. Se convirtió, sin más, en colaborador semiindependiente. Se puede afirmar que ese fue el comienzo de su carrera literaria.

Chatwin se formó como escritor en los artículos que redactó en esta etapa de periodista. Él siempre había dicho que su vida había sido una búsqueda constante de lo milagroso. Los artículos suponen la muestra más clara de esta idea. Transformó cada una de sus experiencias en literatura. Pero el hombre que dio origen a la palabra chatwiniano, el fabulador amante de las contradicciones, el coleccionista que detestaba la posesión, el viajero que coqueteaba con los ricos, aunque siempre votaba a los laboristas no podía permanecer mucho tiempo encerrado. De manera inesperada y sin dar muchas explicaciones, como era normal en él, abandonó el Sunday Times y se marchó a la Patagonia. Dos amigos suyos recuerdan haber almorzado con el escritor en Nueva York antes de emprender su viaje. En el transcurso de la comida anunció, sin darle importancia, su intención de marcharse. Más tarde le vieron con su mochila y sus pantalones cortos, típica imagen viajera de Chatwin, por Broadway, como si estuviera caminando literalmente hacia Patagonia. A la revista les llegó un telegrama donde sencillamente anunciaba "me voy a Patagonia por seis meses".

El resultado de su huida fue la creación de En la Patagonia. El Chatwin viajero se convirtió en un escritor aclamado tanto por el público como por la crítica tras su publicación. El libro presenta los temas que le perseguirán el resto de su vida. Reunió en él una colección de personajes que huyeron de su hogar porque se encontraban más cómodos fuera de él, sentimiento que Chatwin compartía con ellos. La excusa de su viaje a Patagonia fue recuperar un trozo de un supuesto brontosaurio que su antepasado Charley Milward llevó a Inglaterra a comienzos del siglo XX. Con este libro recobra también un trozo de su pasado, de su infancia.

A Chatwin no le gustaba que le consideraran escritor de libros de viajes. De hecho, En la Patagonia contribuyó a cambiar la idea que hasta entonces se tenía sobre el género. Rompió con la tradición al centrarse solamente en la narración de una serie de acontecimientos. No 
relata cómo llegó a tal lugar o cuáles fueron las dificultades que encontró en el camino. Mezcló realidad y ficción con el fin de realzar las vidas de los personajes que eligió como más representativas de la idea que deseaba plasmar en el libro. Para Chatwin el viaje a Patagonia le dio la idea del libro de viajes más antiguo que existía, donde el protagonista emprendía la marcha en busca de una bestia legendaria. La obra levantó discusiones sobre el género al que pertenecía. Muchos se desplazaron a Patagonia con el libro en el bolsillo y volvieron desilusionados al no encontrar lo que habían leído. Incluso algunos personajes del libro le acusaron de inventar excentricidades. Lo cierto es que Chatwin era un viajero literario. No iba por ahí sospechando que la gente fuera aburrida. En la Patagonia jugó a ser un explorador en busca de lo desconocido, como aquellos aventureros del siglo diecinueve que partían a tierras ignotas. La grandeza del libro reside en la manera en la que ironiza acerca de la idea de viajero, ya que ese explorador que parte hacia Patagonia no descubre nada. Termina su periplo en una cueva rodeado de excrementos donde no hay rastro de esa bestia legendaria que había perseguido. Constituye un homenaje a ese viajero genuino que ya bien entrado el siglo veinte ha desaparecido bajo las pisadas del turista.

Con esta obra llega a la conclusión de que lo importante es el viaje en sí mismo, no el fin. Recupera con ello la idea de viaje como metáfora, concepto que abandonó en su inconcluso e imposible estudio sobre el nomadismo La alternativa nómada. Quiso convertirse en el joven héroe que parte con el fin de luchar con un monstruo. Su huida constante hacia el lugar más remoto de la tierra se convirtió además en un intento de comprender el origen del desasosiego humano inherente en la condición humana. Puesto que Patagonia representaba el sitio más lejano de la tierra, lo que hizo fue elevar ese lugar a símbolo de la inquietud humana y escribir un libro, como él mismo confesó, que fuera una especie de metáfora de la nostalgia del espacio. Chatwin otorgó a la cueva de la bestia el honor de representar ese lugar último concreto hacia el cual el hombre, tal y como él mismo estaba haciendo, había huido en busca del origen de su inquietud.

Toda su obra se comprende siguiendo el rastro a esta idea planteada en su viaje a la Patagonia. La obra de Chatwin refleja su propia inquietud. Convirtió su pasión por el viaje en su profesión. Desgraciadamente, sólo algunas de sus odiseas se tradujeron en un libro. Mientras recorría África, Gales, Praga y Australia, escenarios de sus siguientes obras, anotó en sus famosos cuadernos de moleskine aspectos que iban más allá de la simple anécdota. Elaboró con ellos su "anatomía de la inquietud" de la que él hablaba para referirse a ese movimiento constante. Primero se preguntó qué ocurriría si nunca saliéramos de casa. Resolvió el enigma presentando a dos seres anodinos en Colina Negra y a un cruel traficante de esclavos en El Virrey de Ouidah. Describió con ellos los pecados del asentamiento, como él los calificaba, y las consecuencias de la renuncia al mundo nómada.

Con estas dos obras había respondido qué ocurriría si se fuera contra la propia naturaleza y no se emprendieran grandes viajes o se cambiara simplemente de ciudad. Pero aún no había respondido a su pregunta metafísica. Necesitaba comprender el porqué de su ir y venir. Su viaje por la Australia aborigen, descrito en Los trazos de la canción, constituiría la respuesta. Elabora con este libro su biografía espiritual y explica la naturaleza de su desasosiego, ese impulso incomprensible que le alejaba de casa constantemente. Chatwin era incapaz de establecerse en ningún sitio, incluso leía deambulando por la casa. A veces se sorprendía de llegar a su propio domicilio. En Australia, por fin, halló en la filosofía aborigen 
la teoría que le serviría de vehículo a la hora de explicar este sentimiento compartido por tantos. Consigue definirse a sí mismo. Los aborígenes se hallan en la misma situación de Chatwin, en cierto sentido. Emprenden la marcha de manera compulsiva, sienten la necesidad de recrear su mundo en movimiento, pero no saben por qué lo hacen. Buscan lo mismo. A medida que vaga por Australia realiza un recorrido interior que le ayuda a explicar el origen de su inquietud. Llega a la conclusión de que esa necesidad de cambio de paisaje se debe a la existencia de un instinto migratorio inherente en el ser humano, el mismo que obliga a los pájaros a buscar el sur en otoño. Chatwin celebra el movimiento de este modo, porque su vida había sido un constante ir y venir por el mundo. Al mismo tiempo, invita a perderse en Australia. Lo natural en el hombre es emprender un viaje y escapar a este país simboliza precisamente esta idea.

Salmam Rushdie, con el que recorrió en 1984 Australia, comentó a propósito del libro que fue la liberación para Chatwin. Una vez puestas por escrito todas sus ideas acerca de los nómadas, el viaje, el desasosiego y otros tantos temas relacionados, podría crear, hablar o escribir sobre lo que quisiera. La nota triste la pone Rushdie al comentar que Chatwin sólo escribió un libro más, Utz, que sugería algo nuevo (Rushdie 1991: 235). Dejó al lector deambulando por la Praga de un coleccionista compulsivo, un personaje antinómada que renuncia al mundo del arte y la posesión para ser feliz.

Los trazos de la canción termina con la imagen de tres aborígenes moribundos, tendidos al aire libre, esqueléticos, esperando la muerte. Constituye una imagen autobiográfica. El propio Chatwin se creía al borde de la muerte mientras escribía, aunque una mejora inesperada de su estado de salud le permitiría aumentar un poco más su obra literaria. En cualquier caso, tenía la certeza de estar caminando hacia el final y aceptaba con tranquilidad el hecho. Pero la leyenda que siempre le precedió no acaba aquí. La muerte de Chatwin permanece rodeada de misterio. En un principio aseguró que contrajo una infección al comer un huevo negro en China. Negó que fuera SIDA. Tres semanas antes de su muerte apareció un artículo que le anunciaba como víctima de la enfermedad. Nadie duda que el SIDA fue la causa de su fallecimiento. Chatwin murió a comienzos de 1989 a los 48 años pensando que si podía recuperar el uso de sus piernas y volver a caminar, podría curarse, como si el hecho de no poder andar fuera la verdadera causa de sus males y no la propia enfermedad. Murió porque había dejado de ser nómada.

\section{BRUCE CHATWIN Y SUS MOTIVOS DE VIAJE}

Los motivos que animaron a otros a viajar a lo largo de la Historia coinciden con los de Chatwin. Este hecho explica que se identificara con todos esos artistas que se le adelantaron en el planteamiento del porqué de su eterno vagabundeo. Acudió a ellos para indagar acerca del desasosiego humano. Uno de los escritores que más influyó en su imaginación fue Rimbaud, que en mitad de un viaje por África se vio asaltado por la duda y se cuestionó a sí mismo: ¿Qué hago yo aquí? Según él, las razones por las que Rimbaud viajó por Europa, Adén, Abisinia y el desierto de Somalia respondían a una estrategia diseñada para apartarse de la locura y recuperar su salud (Chatwin 1988: 190). Esta afirmación invadía la imaginación de Chatwin, sobre todo en sus últimos días. La enfermedad le acuciaba y soñaba con poder recuperar el movimiento de sus piernas de nuevo. Desvela cuál era 
para el escritor británico la motivación primera de todo viaje: el retorno hacia ese estado primigenio de felicidad, cuando el hombre era nómada y se desplazaba de un lugar a otro, sin cargas. No llegaría a ninguna conclusión convincente hasta la creación de Los trazos de la canción donde explica que lo natural en el hombre es permanecer en movimiento y que la violencia aparece como fruto de la vida sedentaria. Con esta obra se liberó de la obsesión que le había perseguido toda su vida y emprendió un nuevo camino como escritor. Como había asegurado Charles Darwin un siglo antes, la satisfacción de vivir al aire libre, sin duda, constituía un sentimiento inherente al hombre. Esa dicha, como el amor por la caza, era la reliquia de una pasión primitiva. El viajero siempre recordará el extremo deleite que se siente ante el simple hecho de respirar en una tierra extranjera jamás pisada por el hombre civilizado. Chatwin nunca tuvo ocasión de saborear esta sensación de encontrarse en un lugar ignoto, pero llegó a la conclusión de que la mera circunstancia de hallarse en otro lugar que no fuera su casa equivalía a la felicidad. El movimiento permitía recobrar ese estado de plenitud, la reminiscencia de un pasado nómada en el que los hombres vivían dichosos.

A Chatwin le gustaba observarse a sí mismo como un homo viator afectado por la enfermedad de Baudelaire. Sin embargo, su desasosiego nacía de la necesidad de búsqueda de su verdadero yo lejos de una sociedad en la que se sentía juzgado. Siempre se consideró más libre allí donde no tenía que dar explicaciones sobre sus preferencias sexuales. Ni siquiera cuando supo que sufría SIDA reconoció públicamente su homosexualidad. El viaje como huida cuenta con innumerables adeptos y constituye un motivo que ha prevalecido a lo largo de los siglos en numerosos escritores de libros de viajes. Ya el hombre medieval utilizaba el viaje como excusa para la fuga. Mediante la peregrinación y la romería se buscaba la purificación. En los siglos XII y XIII, Asia era el espacio soñado hacia donde los viajeros dirigían sus pasos y el lugar al que se referían los libros de viajes como el paraíso terrenal. Comprendía una zona cuya ubicación no se corresponde con el actual. Simbolizaba, por encima de todo, un territorio utópico donde se conservaba ese estado de felicidad anterior al pecado original, ese bienestar al que aspiraba Chatwin con sus peregrinajes. Se creía que cerca de la India se hallaba el Edén. Cuando Colón llegó a América vio en esas tierras ese espacio glorioso donde los sueños de los hombres se convertían en realidad. Ajustó ese entorno al espacio imaginario medieval. Durante siglos, América había representado para la cultura occidental un gran sueño que por fin se materializaba. Chatwin no necesitó un sitio concreto con el que identificar el paraíso. Fueron muchos los lugares que lo representaron. Idealizó cada uno de ellos convirtiéndolos en arcadias íntimas.

Esta fascinación por Oriente resurgió en el siglo XIX de la mano de exploradores como Richard Burton o Lawrence de Arabia. El primero de ellos, arquetipo de los grandes aventureros de la época decimonónica inglesa, huyó a la India, África, Oriente, América y Europa en busca de oxígeno, lejos de la Inglaterra puritana que lo asfixiaba. Una de las obsesiones de Burton, por ejemplo, era traer a Occidente la sensualidad de Oriente. Esa fascinación se traducía en la búsqueda del exotismo. Oriente simbolizaba ese territorio lejano y extraordinario donde se podía experimentar una libertad imposible en casa. En la imaginación de Gustave Flaubert, encarnaba ese rincón al que podría huir lejos de la aburrida Rouen. Más tarde, en el período comprendido entre la Primera y la Segunda Guerra Mundial, una gran cantidad de escritores halló la felicidad lejos de su hogar huyendo de una Inglaterra, según su criterio, inhabitable. Algo más que la curiosidad impulsó a Lawrence 
Durrell, W.H. Auden o Norman Douglas, entre otros, a escapar de una sociedad en la que se sentían constreñidos. El ambiente de inhibición de la sociedad británica en la que vivieron personajes como Sir Richard Burton, Norman Douglas, Harry St. John Philby, Robert Byron o Gavin Maxwell les obligó a huir. Fuera de su país tuvieron la posibilidad de contemplar horizontes morales más amplios, a pesar de que en ocasiones debían convivir en culturas tan poco liberales como la suya propia. Pero fuera de su nación, ellos eran meros visitantes, no ciudadanos. Gozaban de mayor libertad. De este modo, Richard Burton desoía las amenazas de persecución que implicaba su propósito de traer a Occidente la sensualidad oriental. Igualmente, si Maxwell se hubiera encontrado en su Escocia natal con la actitud más abierta hacia la homosexualidad de los países norteafricanos, se habría sentido con toda seguridad más satisfecho consigo mismo. Incluso hoy en día, el viajero, por el mero hecho de ser extranjero, se siente libre de hacer lo que desee una vez fuera de su entorno, lejos de las tradiciones de su propio país, como fue el caso de estos viajeros británicos. En todos ellos, como en el caso de Chatwin, el extranjero alude a ese espacio donde todo es posible lejos de los convencionalismos de la patria. Expresaron en sus obras la huida de este confinamiento moral y la búsqueda de su paraíso. No constituyen, sin embargo, los motivos únicos que les empujaron a partir. Incorporan, sencillamente, dos aspectos más que deben tenerse en cuenta a la hora de analizar la dialéctica que mantiene ocupada la mente del viajero. Su imaginación se debate entre el hogar y el paraíso. Permanecer en Gran Bretaña representaba en cierto modo un límite, sobre todo porque encarnaba lo ya conocido. El viaje les ofrecía la opción de embarcarse en lo ignoto, independientemente de lo que se encontraran más allá de sus fronteras y de lo que posteriormente relataran en sus obras.

Esta dicotomía entre el hogar y lo exótico se repite en un número elevado de viajeros y escritores ingleses. Se trata de una liberación inherente a toda experiencia viajera. El que emprende la marcha siempre será un ser libre allá donde vaya. No se siente obligado a seguir las costumbres de los que le rodean y al mismo tiempo está libre del cumplimiento de toda obligación del país de procedencia. Chatwin hizo del extranjero su hogar convirtiéndose así en un exiliado, continuando la tradición británica. Sus aventuras conformaban una táctica diseñada para combatir el aburrimiento. Se huye de lo conocido hacia la diversión que supone entregarse a costumbres ajenas. En el caso de otros escritores de libros de viajes, como Graham Greene, por ejemplo, esa fuga del aburrimiento les llevaba a organizar viajes arriesgados donde ponían en peligro su propia vida

El afán de conocimiento ha sido otro de los motivos históricos para emprender la marcha. Este motor cobró fuerza sobre todo en el siglo XVIII. El viaje ilustrado se caracterizaba por poseer una finalidad didáctica y formativa. Lejos de ser sinónimo de aventura o placer, representaba para pensadores como Rousseau una actividad sólo válida si el viajero era capaz de observar y criticar. Constituía una experiencia educativa que contribuía a difundir las ideas del mundo de las luces. El hecho de realizar el recorrido de las ciudades comprendidas en el itinerario del Grand Tour era una convención de obligado cumplimiento entre las clases media y alta tras la finalización de los estudios universitarios. Dotaba al viajero de una educación liberal. Al limitarse a un recorrido prefijado de ciertas ciudades europeas, desaparecía el verdadero motivo por la superficialidad de semejante empresa.

En el siglo XX ese afán de conocimiento queda restringido a los límites de uno mismo. Chatwin deseaba saber más sobre su propia identidad. Su viaje, además de iniciarse con 
la ilusión de recorrer espacios desconocidos, implicaba una búsqueda del yo. Chatwin emprendió su viaje a Sudán, fundamental en su carrera literaria, porque necesitaba una respuesta. Una ceguera psicosomática, provocada por la infelicidad que le producía su trabajo en el negocio del arte, le empujó a perseguir las raíces de su idiosincrasia. El resultado de ese periplo fue la decisión transcendental de dedicar su vida a explicar el origen del impulso nómada. Alumbró, con este fin, una primera obra, En la Patagonia, cuyo protagonista es el paraje más remoto de la tierra. Una representación de la inquietud humana: "El hombre no había caminado más allá de Tierra del Fuego -le comentó a Gnoli- en cierta forma Patagonia es el símbolo último del desasosiego humano" (Shakespeare 1999: 291). De ahí, viajó al polo opuesto con El Virrey de Ouidah, su siguiente libro. Tras celebrar la lejanía de la patria, buscó la historia de las consecuencias del asentamiento. Cambia la perspectiva con la que enfocó el tema del horror al domicilio. Construye en apenas 130 páginas la historia del traficante de esclavos brasileño Dom Félix de Souza. A través de su protagonista analiza la personalidad del hombre que aniquila el impulso nómada para obtener éxito con su negocio.

La sed de aventura ha sido también motivo para acometer arriesgadas andanzas. Se puede afirmar que constituye uno de los fenómenos más recurrentes entre los viajeros de todas las épocas, una motivación que puede hallarse incluso en los escritores de libros de viajes contemporáneos. Famosa es la frase de Edmund Hillary en la que confiesa: "Si no fuera tan peligroso llegar a la cumbre, escalar el Everest sería la cosa más aburrida del mundo. Nosotros subimos porque nadie lo había hecho antes". Sólo el resorte aventurero pudo empujar a Wilfred Thesiger a arriesgar su vida por descubrir la desembocadura del río Awash. Esta necesidad de aventura se traduce, en la mayoría de ocasiones, en una identificación cultural con los pueblos que recorren. Se produce una especie de fusión personal con la nueva tierra y sus gentes provocando una huida de la propia patria de origen. En el caso de los exploradores del siglo XIX como Livingstone, Selous o Stanley, su primer encuentro con África les obligó a no renunciar jamás a esta tierra que les cautivó. Sus viajes al continente negro fueron innumerables e incluso los dos primeros fallecieron allí. Otro caso significativo es el de T.E. Lawrence, para siempre asociado a su leyenda árabe.

Chatwin también recibió la llamada de la aventura, pero el original escritor dio un giro al punto de vista utilizado para narrar sus andanzas. En épocas anteriores, el riesgo equivalía a la adquisición de cierta consideración social. El explorador que había alcanzado la cima más alta del mundo se convertía inmediatamente en un héroe. Los viajeros británicos del siglo XIX que regresaban sanos y salvos a casa encontraban a su vuelta el reconocimiento oficial de la prestigiosa Sociedad Geográfica. Esta distinción pública que emanaba de los viajes a lugares remotos incitaba a muchos viajeros de la época victoriana a abordar sus aventuras. Su retorno al hogar, donde les esperaba la celebridad derivada de sus investigaciones o descubrimientos, justificaba sus osadas empresas. Existía una estrecha relación entre el éxito profesional y los viajes, ya que durante el transcurso de éstos se alumbraban descubrimientos que activaban la expansión del Imperio Británico. A los hallazgos científicos, se unía la creación de nuevas rutas que impulsaban la colonización. En este contexto, la labor de la Sociedad Geográfica Británica constituía un componente esencial debido a ese vínculo existente entre las labores científicas de la institución y los intereses políticos. Era un punto de reunión de todos aquellos involucrados en la tradición imperial británica. La pertenencia o reconocimiento de esta selecta institución equivalía a 
la adquisición de una posición social y económica elevada. El dato explica que la Sociedad Geográfica contara con tantos cargos militares y funcionarios coloniales. Los viajeros fueron expertos en asegurarse el triunfo una vez que habían regresado al hogar. Ponían sus viajes al servicio del Imperio. Sus aventuras tenían como resultado el trazado de un mapa, se traducían en datos científicos de gran valor o abrían rutas comerciales. Cuando la aventura llamó a la puerta de Chatwin la época del Imperio quedaba ya muy lejana. Decidió utilizar esa llamada con fines puramente literarios. Su obra En la Patagonia juega a dibujar a un explorador en busca de lo desconocido, como aquellos aventureros del siglo XIX que partían a tierras vírgenes en busca de prestigio y riqueza. La grandeza del libro reside en cómo ironiza acerca de la idea de viajero. Ese explorador que parte hacia Patagonia no descubre nada. Termina su periplo en una cueva rodeado de excrementos donde no hay rastro de esa bestia legendaria que había perseguido, principal motivo de su aventura. Al mismo tiempo, rinde homenaje a ese viajero genuino que ya bien entrado el siglo XX ha desaparecido bajo las pisadas del turista. La aventura, tal y como se concebía en las primeras incursiones en territorios vírgenes de exploradores como Speke o Burton, ya no existía. Joseph Conrad dice en El espejo del mar (Conrad 1982: 40) que a nadie se le ha presentado nunca la aventura cuando la ha llamado. Es ella la que escoge a los mediocres mortales. Chatwin desembarcó en escenarios donde la uniformidad constituía un rasgo irreversible. Aun así partió en busca de un aspecto original que diferenciara a las gentes y a los paisajes visitados. Logró encontrar su tesoro aportando una mirada singular, abriendo nuevas perspectivas. Su aventura consistió en contemplar otras realidades con su propia mirada. Se presentó al lector como un simple narrador de historias.

De todas las motivaciones arriba descritas es el viaje como descubrimiento de uno mismo la que más ha influido en la literatura de viajes y la que más ha contribuido al desarrollo del género. El viaje como símbolo de otra idea. Graham Green, el padre del viaje psicológico, utiliza su periplo por tierras africanas (Green 2002 :18) como excusa para describir un viaje que se convierte en metáfora de la búsqueda de las propias esencias. Green busca una clase de hazaña lejos de los estereotipos de la literatura de viajes con la que se alimentó de joven. Pertenece a una generación desilusionada tras el horror de la Primera Guerra Mundial, por lo que su viaje no encaja en los modelos de aquellos libros de aventuras. Su escapada sólo puede ser un viaje subjetivo. En Journey without maps transita por la jungla de su niñez.

Para Chatwin, al igual que para Greene, el viaje constituye una metáfora de la vida y el modo de expresión religiosa más antiguo que existe. La lucha contra ese impulso equivale al rechazo de un instinto natural en el ser humano que inevitablemente le conduce a la infelicidad. La existencia es un espacio que debe recorrerse, una peregrinación hacia ese objetivo último que es la muerte. Un final del que además paradójicamente se huye. El camino representa el transcurrir de toda una vida. Ese desplazamiento se basa en una progresión lineal, pero también eleva al viajero hacia un estadio espiritual superior que le convierte en otra persona una vez finalizado el periplo. Chatwin plasmó en cada una de sus obras esa transformación fruto de cada uno de los pasos dados en el camino. Los protagonistas de sus obras dibujaron el sendero que todo ser humano supera. Sus personajes crecen a medida que avanzan en la narración. Los viajes que realizan o los no viajes, como los mellizos Benjamin y Lewis de su obra Colina Negra, constituyen una metáfora de la propia existencia humana, avanzan en busca de esa felicidad que un día dejaron atrás. En 
esta novela, Chatwin dibuja una de las imágenes más poéticas de su obra donde explica cómo una serie de sucesos sólo se llegan a comprender una vez vividos cada uno de los acontecimientos. Un viaje da sentido a toda una existencia. La escena tiene lugar cuando los hermanos reciben como regalo de su ochenta cumpleaños un viaje sorpresa siguiendo una antigua costumbre inglesa en virtud de la cual una pareja emprende un viaje sin saber el destino del mismo. Después de recorrer varios kilómetros, recalan en un aeródromo donde se embarcarán en un avión. Benjamin siente pánico y Lewis permanece estupefacto. Una vez que ya están en el aire, sin embargo, Benjamin se relaja cuando él y Lewis ven la granja desde allí arriba. Observan su existencia, concentrada en La Visión, con la perspectiva de todo lo vivido. Lewis llega, incluso, a pilotar el avión con lo que se libera de todas sus desilusiones: "Las frustraciones de su vida mezquina y frugal no contaban para nada, porque, durante diez magníficos minutos, había hecho lo que quería hacer" (Chatwin 2003: 321). Toda su vida recobra sentido, porque le parece un período preparatorio para esos pocos instantes en el cielo en los que maneja su vida (pilota él mismo el avión). Puede hacer lo que realmente ha soñado siempre. Unas indicaciones del piloto, que no comprende en principio, le hacen dibujar en el aire el número ochenta, escena que simboliza la manera en la que funciona la vida, una serie de sucesos que sólo se llegan a comprender una vez vividos cada uno de los acontecimientos, tal y como le ocurre a Lewis. El capítulo termina con los mellizos intentando encontrar el lugar perfecto en el que colgar una foto aérea de la granja. No saben dónde colocar algo tan significativo en sus vidas y se sienten perdidos porque nada se había añadido a la casa en mucho tiempo. El gesto adquiere más trascendencia aún. Benjamin aporta la solución: “Que desplazando al Tío Eddie y el oso pardo, y desplazando lateralmente a Hannah y el Viejo Sam, quedaba justo el espacio suficiente para acomodarlo junto al grupo de la boda de sus padres" (Chatwin 2003: 322). A través de esas fotografías ellos han ido reconstruyendo su historia y han estado allí colgadas recordándoles cuáles eran sus orígenes. La novela en sí misma ha ido dibujando también ese círculo en el que todos los sucesos cobran un significado. El primer capítulo de la novela comienza precisamente con la descripción de ese lugar de la casa hacia donde con sólo mirar podían situar el germen de su existencia. Sólo faltaba esa foto aérea del episodio tan relevante del vuelo que sirve como catalizador para que cuajen los acontecimientos.

Chatwin buscó el paraíso en sus viajes. Llamado por la aventura emprendió exploraciones que le condujeron a un conocimiento profundo de sí mismo con una primera parada en Patagonia y una última en Praga. Huyó de un espacio geográfico y social limitado para desprenderse del peso de las posesiones a las que le ataban los objetos. Como si se tratara de un caballero en busca del Santo Grial, Chatwin se convirtió en el héroe que crecía como escritor a medida que avanzaba en su viaje. Su camino se fue construyendo a través de cada una de sus obras. Gracias a ellas creció como creador y averiguó, finalmente, el emplazamiento de su paraíso personal.

\section{CHATWIN EN EL MARCO DE LA LITERATURA DE VIAJES DEL SIGLO XX}

La evolución experimentada en la literatura de viajes no se produjo de manera gradual. No hubo un desarrollo progresivo que condujera con el paso de los siglos desde la narración lineal con un orden cronológico estricto hasta un extremo literario. En el siglo XX conviven 
obras concebidas bajo estos dos principios radicalmente opuestos. Las enormes diferencias formales no impiden que una obra concebida bajo los principios y fines de los escritores de siglos anteriores continúe englobándose bajo la etiqueta de libro de viaje. Este aspecto ha contribuido a la confusión en cuanto a la clasificación genérica de la literatura de viajes y explica que obras tan dispares como las firmadas por autores como Eric Bailey y por P. L. Fermor coincidan en el tiempo. A pesar de que el primero publicó No Passport to Tibet en 1957, un mes antes que la poética Mani del segundo, su estilo se acerca más al de sus predecesores victorianos. Mientras Fermor será recordado ante todo por su mérito como escritor, Bailey pasará a la historia como un gran explorador de escaso valor literario, como otros tantos escritores de viajes. Sus obras no fueron más que una continuación de su personalidad. El gran aventurero gozaba de una idiosincrasia poco proclive a la comunicación. Su humildad no favoreció que pasara a la historia, como fue el caso de otros famosos exploradores. Irónicamente, esa tendencia a la discreción y la mesura expresiva le permitió introducirse en algunos lugares donde otro tipo de personalidad hubiera fracasado en el intento. Sin embargo, no supo transformar ese rasgo personal en literatura.

Una vez que cada lugar desconocido del planeta había sido ya recorrido, cada río surcado y cada paisaje descrito por la pluma de un escritor, autores como Chatwin volcaron su creatividad en la elaboración de textos donde la literatura transmitía sentimientos, opiniones y visiones personales. Pero hasta la llegada a este punto crucial, el autor se erigía en primer lugar como explorador y después como creador. Es más, su obligación consistía en la transmisión de una serie de hechos verdaderos que dibujara en la mente del lector europeo una imagen lo más cercana posible a la realidad del país ignoto. El fin didáctico era el denominador común de prácticamente casi toda la literatura de viajes. Este rasgo aún pervive, pese a la gran evolución que ha experimentado el género. En autores como Bailey, sin embargo, constituía un componente primordial. Su deseo respondía, además, a las expectativas del tipo de sociedad que esperaba su regreso. Sus lectores demandaban información y ello daba pie a minuciosas descripciones donde se revelaba esa pasión por los datos. La exactitud y la precisión llevó a escritores como el anteriormente citado al relato lineal de sus observaciones sin ninguna ordenación temática. Los sucesos se narraban a medida que ocurrían. Sólo la indicación de la fecha o la especificación del lugar de la ruta donde este acontecía regulaba la acumulación de datos. La carencia de discriminación llevaba a la enumeración, por ejemplo, de los productos de una curtiduría en un párrafo y al relato de las prácticas sádicas de un oficial chino en el siguiente. Esta aparente falta de moral, producto de esa búsqueda por la plasmación de una serie de hechos, será una característica que desaparecerá en escritores como Chatwin. Una vez que la subjetividad entra en el escenario de la literatura de viajes, prevalecerá el punto de vista del viajero. Cómo cuente su historia determinará su éxito entre los lectores. En el caso de Chatwin, su percepción de la realidad supondrá un cambio tan brusco frente al relato descriptivo tradicional que incluso se le acusará de ser engañoso. Por ejemplo, Los trazos de la canción, tal y como ocurrió con En la Patagonia, levantó discusiones sobre el género al que pertenecía. Chatwin defendió ante sus editores que se trataba de una obra de ficción e hizo referencia, con cierta satisfacción, al término español novela de viaje aplicable a Don Quijote. Cuando Michael Ignatieff le preguntó dónde se establece la división entre ficción o no ficción en su obra, Chatwin replicó que no existe tal linde. Mezcló anécdotas falsas y experiencias reales de su 
viaje. Mientras que En la Patagonia, confiesa, pudo contar las mentiras incluidas en la obra, en Los trazos de la canción no podría repetir la misma tarea puesto que lo más significativo del libro sólo podría calificarse de obra narrativa (Ignatieff 1987: 5).

La belleza de su obra radica precisamente en el color que confiere a sus anécdotas. Acusarle de falsedades sería obviar las complejidades de un género aún hoy en evolución. Estrabón afirmaba que todo viajero mentía. El geógrafo griego (siglo I) consideraba este defecto una virtud. Sólo aquel que añadía imaginación a las experiencias lograba cautivar a sus lectores. Si Chatwin se hubiera limitado a describir su viaje tal y como aconteció, su obra hubiera pasado inadvertida. Quedaba muy atrás la época en que el único requisito exigido al escritor de libros de viajes consistía en la plasmación precisa del lugar visitado. Para Paul Fussell (Norton Book of Travel: 16) el género oscila entre dos polos: el mundo físico que se describe y el tema universal sobre el que trata el libro en cuestión. Las obras de Chatwin se mueven entre estos dos polos. En ellos describe paisajes y gentes pero, al mismo tiempo, indaga en el problema metafísico universal que le embargaba, es decir, el origen de la naturaleza viajera del hombre. Este camino creativo que eligió le alejará de la gran novela urbana del siglo XX, la que representan autores como Marcel Proust, James Joyce o Franz Kafka. La obra de Chatwin prolonga una línea de pensamiento que vincula la reflexión sobre el hombre con la relación de éste con la naturaleza. Sus antecedentes deben buscarse en las páginas de escritores como Daniel Defoe, Herman Melville, Jack London o, incluso, Ernest Hemingway. Su aportación al género consistió en la originalidad temática a través de la cual construyó su obra y en la utilización de todas las estrategias literarias a su alcance para la resolución de la incógnita que provocaba su desasosiego. Llegó incluso hasta novelar para descubrirla. Fue un viajero mentiroso que cautivó a sus lectores con la narración de su periplo interior.

En el siglo XIX sobraban en la mente del explorador las descripciones donde se intentaba transmitir la belleza del paisaje o cualquier otro sentimiento nacido del encuentro con nuevas tierras y gentes. La entrada en escena de escritores que comunican algún tipo de emoción supondrá un cambio cualitativo en esta categoría de relatos. Chatwin, lejos de caer nunca en ofrecer al lector una visión mítica o romántica del lugar descubierto, forma parte, en este sentido, de este tipo de autores. Su búsqueda más de una idea que de un paisaje determinado le elevarán a una clase especial de escritor de libros de viajes. Siguiendo la estela de autores como Wilfred Thesiger, conseguirá contagiar al lector su inquietud acerca de la naturaleza viajera del hombre.

Si se sigue contraponiendo la obra de Chawin a aquellas de los tradicionales escritores de libros de viajes, se observa otro rasgo fundamental que sitúa al narrador británico entre los más vanguardistas de su época. En menos de un siglo se percibe un cambio radical en el grado de implicación de los artistas con el entorno visitado. No sólo existía frialdad en las descripciones paisajísticas de los autores como Bailey, sino también en las representaciones humanas incluidas en sus obras. En el caso concreto de Bailey sólo definía las características de sus acompañantes de acuerdo al beneficio que podía obtener de su contacto con ellos. Si las gentes con las que se cruzaba en el camino mostraban algún tipo de suspicacia, no intentaba ponerse en su piel y reconocer su miedo a lo desconocido, sino que aprovechaba la ocasión para descalificarlos. La razón por la que estos hombres mostraban este tipo de actitud debe buscarse en el hecho de que no los consideraban sus iguales. Bailey ni siquiera 
les distinguía como individuos. En sus obras es difícil encontrar el nombre de algún indígena de los que le ayudaron en sus periplos en Asia, por ejemplo. Darwin, un siglo antes, también había despreciado a los nativos patagónicos tachando su evolucionado idioma de lenguaje primitivo. Tradicionalmente se prestaba atención a los métodos agrícolas o vestimenta de los habitantes autóctonos, pero los aspectos meramente humanos, como sus creencias, no despertaban apenas interés. El viajero era un mero espectador que observaba y tomaba nota de una serie de datos. El tipo de relación necesario para comprender o llegar a conocer las inquietudes inherentes a estas nuevas sociedades con las que entraban en contacto implicaba una clase distinta de actitud frente al nativo de la que ellos no gozaban. La catalogación era una forma de autoproclamarse los amos. Poco les importaba que esos animales, montañas o ríos que ellos veían por primera vez ya hubieran sido bautizados por las gentes del país. La supremacía militar y económica europea les había permitido repartirse el mundo a su antojo. El desprecio por la nomenclatura primitiva de esos pueblos revelaba una forma de dominio muy evidente y no dudaban en llevarla a la práctica. Uno de los ejemplos más significativos lo ofrece el cambio de nombre que sufrió la montaña denominada por los tibetanos ChomoLungma (Diosa Madre de la Tierra) que el gobierno británico llamó Everest en honor a Sir George Everest. Posicionándose en una línea totalmente antagónica, Chatwin, durante su viaje a Patagonia y a Australia, mostró una gran preocupación por el tratamiento recibido por los nativos de aquellas tierras. Denuncia abiertamente las injusticias cometidas contra unos pueblos invadidos por Occidente y obligados a sobrevivir en la marginación. Chawin, asegura su editora Susannah Clapp, opinaba que había publicado Los trazos de la canción para celebrar el rigor de los aborígenes:

En una cena en Sydney, un hombre muy inteligente discutió conmigo; dijo que nunca había encontrado aborígenes; dio a entender que los aborígenes eran ajenos a la realidad australiana. Entonces recobré la voz y dije que los aborígenes, o su destrucción eran tan importantes como la Colonia Penitenciaria en la conciencia de los australianos (Clapp 1997: 255).

Por otra parte, la actitud de superioridad de aquella época no despertaba malestar en los lectores. La complicidad entre el receptor y el narrador del viaje hacía posible que se estableciera una comunicación fluida entre ambos. Ésta constituye una característica que ha perdurado, desde los primeros textos de viajes hasta los más modernos del género. En todo relato de viajes existe una serie de suposiciones morales y culturales comunes a ambos. Sin esa herencia cultural, los comentarios u observaciones apuntadas por el autor carecerían de sentido. El escritor conoce los límites del lector, sabe que ignora cierta información. Sólo de este modo es capaz de saciar su curiosidad, ya que elige los datos que le dejarán satisfecho. Esta es la razón por la que el viajero, hasta bien entrado el siglo XX, no es más que un mero espectador de otra cultura u otro paisaje. No trata de describir desde el yo subjetivo, porque sabe que un ávido lector espera que le cuenten cómo es lo desconocido. Sólo cuando ese lector haya visitado aquellas tierras ignotas se preocupará por otras perspectivas.

La herencia cultural del escritor de libros de viajes determina también de manera llamativa la perspectiva con la que se narra el relato. Un ejemplo significativo lo simboliza el caso de Harry St. John Bridger Philby. Su erudición supuso un obstáculo a la hora de transmitir la cultura islámica que tanto amó. Su pensamiento poseía un enfoque 
profundamente occidental que limitó su acceso a esta cultura, a pesar de haberse convertido a esta religión. Por el contrario, Chatwin intentó en sus obras sobre Patagonia, Australia y África ponerse en la piel de los menos privilegiados, es decir, los nativos de aquellos países invadidos por las sucesivas oleadas migratorias. A pesar de poseer una perspectiva occidental de la que nunca podrá desprenderse, intentó comprender el espíritu de aquellos que estuvieron en esa tierra antes que él. Vertió una dura crítica a la forma en la que se había profanado el paraíso nativo. El edén de los viajeros que se instalaron en Patagonia o en Australia se construyó sobre los escombros de unos pueblos que vivían en su olimpo. Con la llegada de los invasores, debieron conformarse con el infierno de la marginación. Chatwin, al verter esta crítica, se convierte en un escritor de su tiempo, en un autor preocupado por la sociedad en la que vive. Denuncia sus males y lucha con la palabra contra las injusticias cometidas por su propia cultura. Al mismo tiempo, plantea la paradoja del viajero. Cuando Chatwin dibuja a su personaje más exquisito en El Virrey de Ouidah vuelca en el traficante de esclavos Dom Francisco todas las complejidades de su obsesión por los males de la estabilidad. El que se estanca en la habitación o dedica su existencia a recluir a otros, como su personaje, se ve trasladado inevitablemente a un estado de infelicidad y desasosiego.

Los horrores de la Primera Guerra Mundial serán los que provoquen un cambio en la perspectiva con la que los viajeros observaban la realidad del planeta. La confianza en ese nuevo mundo donde el progreso de la humanidad parecía resolver todos los problemas, tan característico de los grandes exploradores del siglo XIX y principios del XX, desaparecerá con la desilusión de la guerra. Imperará un sentimiento de desengaño y desgaste moral. Para el historiador Paul Fussell (Fussell 1982: 21) el viaje se convierte entonces en la metáfora literaria dominante. Será la excusa utilizada para expresar todo tipo de inquietudes existenciales. Una oleada de nuevos escritores de viajes llenará el espectro literario británico. Son numerosos los que huyen de esa atmósfera de pérdida de ilusiones. Buscan en el exilio, lejos de su hogar, un consuelo para la pérdida de la esperanza. Esta fuerza centrífuga es el antídoto a ese sentimiento de aburrimiento y opresión que les invade en su patria. Chatwin heredará esta idea del exilio. Todos sus personajes viven de una u otra forma desterrados, huyendo de una realidad opresiva. En el caso del coleccionista compulsivo de su obra Utz, se observa como éste huye en busca de una parcela lo más alejada posible de su esposa. Sus viajes a Vichy descritos en el libro representan en cierto modo esa escapada lejos del hogar, un modo de liberarse: "Hacia abril, también experimentaba una claustrofobia aguda, producto de haber pasado los meses de invierno muy cerca de Marta, que no cesaba de adorarlo" (Chatwin 1997: 84).

Este período marcado por los exilios literarios favorecerá, sin duda, el florecimiento del género. Propiciará, además, el desarrollo de un tipo de escritor que se cuestiona no sólo a sí mismo sino también al mundo que le rodea. El gigante en este período de entre guerras será Robert Byron, tan admirado por Chatwin. Éste, a través de la ironía, criticará las normas del mundo moderno que le tocó vivir. Famosa es la descripción que esculpe de un turista americano obsesionado por el dinero con el que se encuentra durante su viaje a Oxiana (Byron 2001: 65). El americano, más pendiente de la siguiente parada que del camino recorrido, insiste en que tiene mucha prisa y que carece de tiempo para entretenerse en conversaciones banales en las que no halla la información que precisa. Con la introducción de este personaje, Byron traza un retrato irónico del arquetipo de viajero 
que pronto se impondrá en una sociedad donde el viaje perderá el sentido dado por los exploradores anteriores.

Como su admirado Byron, Chatwin también cuestiona el sentido del viaje y la sociedad que le rodea. El protagonista de la Praga soviética de Utz, realiza un viaje en tren a Vichy, durante el cual será testigo de la insolidaridad del mundo occidental que admiraba desde su reclusión en la Europa Oriental. Deberá compartir asiento con un matrimonio joven que le negará la ayuda. Será el preludio de la soledad que invadirá sus días de libertad soñada. Chatwin construye una escena magistral en la que describe cómo una mujer engulle egoístamente una cantidad ingente de comida mientras Utz, famélico, implora con la mirada un trozo de naranja. La dama no sólo desdeña la súplica de compartir lo que a ojos de Utz son manjares, sino que prefiere arrojar los restos por la ventana antes que ofrecerle las sobras. Este infortunio le anuncia la infelicidad que presidirá sus días occidentales: "Utz observó cómo este pequeño drama llegaba a su inevitable desenlace y murmuró en alemán, con suficiente volumen de voz para que ella oyera: Nunca podría haber ocurrido en Checoslovaquia" (Chatwin 1997: 66). Desde el primer momento, al protagonista no le satisface nada de lo que había soñado de Occidente. No disfruta de su viaje y tiene la impresión, al observar la decoración del hotel donde se aloja, de que los franceses han perdido, incluso, el buen gusto.

Los años de la posguerra pondrán fin al periplo tan valorado por Byron y los escritores de los años treinta. Los nuevos medios de transporte traerán consigo el turismo de masas y el fin del éxodo como experiencia personal independiente. Miles de personas visitarán los mismos lugares en busca de lo auténtico, es decir, de la versión real de los monumentos tantas veces descritos. Pero esta pasión por lo lejano degenerará el viaje hasta transformarlo en un simple peregrinaje hacia grandes almacenes culturales. Tras la Segunda Guerra Mundial este problema se acentuará al incrementarse la homogeneidad en el mundo. Se dará comienzo a la articulación de una cultura de masas que elimina esos lugares a los que los auténticos viajeros se escapaban en busca de lo éxotico. Resultará difícil encontrar un sitio donde no se hallen prácticamente las mismas cosas que en el hogar. Desaparecerá el concepto de viaje como lo habían entendido escritores de relatos de viajes como Wilfred Thesiger, influencia decisiva en Chatwin.

Esta circunstancia favorece el nacimiento de una generación de literatos que se resisten a vivir la experiencia del viaje de esta manera y que buscan la complejidad, la autenticidad y una nueva forma de observar el mundo. Ellos formarán los valores emergentes de la literatura de viajes. Tratarán de retener elementos distintivos en un mundo caracterizado por la similitud, es decir, por lo que el antropólogo y escritor de libros de viajes Lévi-Strauss llama la monocultura en su obra Tristes Trópicos (Lévi-Strauss 1988: 42). Buscan un antídoto al mundo materialista y conformista que les rodea. En el camino de Jack Kerouac simboliza el tipo de viaje al que aspiraban este grupo de escritores inconformistas.

Chatwin será heredero de esta primera oleada de "viajeros antisistema". La diferencia más significativa con la generación anterior será que estos últimos no habrán perdido la capacidad de asombro, como es el caso de Chatwin. Paul Fussell (1982: 166) les denomina la generación del post-turismo. Son autores marcados por la misma tendencia hacia el aburrimiento, la desilusión y la rabia mostrada por los escritores de la época anterior, pero con una diferencia vital. En el enfoque de sus narraciones dominará la reflexión, el humor 
negro y el cinismo. Chatwin supone un claro ejemplo. Cuando En la Patagonia el autor llega a la cueva descubre que el objeto de su búsqueda resulta ser un detrito y no el mítico brontosaurio símbolo de un sueño infantil.

El viaje, para autores desde Herodoto hasta Darwin, implicaba la recopilación de datos y anécdotas que luego relataban a sus lectores. Sabían que estos sólo les exigían la verdad. En los escritores de finales del siglo XX se observa un cambio radical de perspectiva, no sólo porque se enfrentan a un mundo conocido por sus lectores, sino también porque perciben que el universo son ellos. Sus puntos de vista aportan significado a lo que observan y enseñan a sus públicos a descubrir el mundo bajo su mirada. Se acercan más a la gente con la que se tropiezan en su camino e incluyen más de sí mismos, porque esa subjetividad confiere más valor a su relato. Se despegan de las descripciones geográficas y pisan territorios emocionales.

Cuando los autores de literatura de viajes de finales del siglo XX se cuestionan todo lo que les rodea, incluso a ellos mismos, convierten sus obras en la antítesis de lo que fueron en origen, es decir, el reflejo fiel de la realidad. A medida que avanza el siglo aparecen más ejemplos literarios donde se desvanece la línea que separa ficción y realidad, llegando al extremo con Bruce Chatwin. Sus dos obras más visiblemente clasificables bajo la etiqueta de libros de viajes, En la Patagonia y Los trazos de la canción, podrían no considerarse siquiera pertenecientes al género. Chatwin jugó con esa división entre lo real y lo ficticio e incluso se resistió a ser denominado escritor de libros de viajes. Deseaba alejarse de una categoría que limitaba sus posibilidades creativas. Siempre rozando la línea entre lo palpable y lo inventado, incluyó en sus libros tanto vivencias personales como sueños. A través de ellos intentó explicarse a sí mismo el origen del desasosiego. Esta autorreflexión daba, además, sentido y profundidad a su viaje. Su presencia en otra tierra propiciaba el desencadenamiento de esos pensamientos hondos que explicaban su alma viajera. Chatwin dio un paso más. El viaje se convirtió en una simple excusa para la narración de una historia plenamente nacida de la imaginación. Como dice Melville en Moby Dick a propósito del lugar de procedencia de su personaje Queequeg: "No figura en ningún mapa: los lugares verdaderos nunca figuran en ellos" (Melville 2001: 98); del mismo modo, Chatwin recreó los países visitados de una forma totalmente personal. Los que siguieron sus pasos no hallaron lo que Chatwin plasmó en sus libros. Nunca pretendió crear caminos precisos para que los lectores le siguieran. Aquellos que así lo hicieron partieron con una premisa equivocada. Chatwin describió su viaje bajo una perspectiva original; porque constituía una experiencia íntima y personal. Los que rastrearon la línea de su pensamiento, no el itinerario físico, no se sintieron defraudados al llegar al destino. Comprendieron la trascendencia de su mensaje. $\mathrm{Su}$ viaje era sólo una excusa para reflexionar sobre la inquietud.

\section{CONCLUSIONES}

Las disquisiciones entorno a la clasificación de la obra de Bruce Chatwin realizada en el presente artículo explicitan su complejidad. No se puede afirmar con rotundidad que respondiera a la etiqueta de escritor de libros de viajes. Tampoco a la de autor de obras de ficción exclusivamente. Aunque recurrió a la narración de un viaje como excusa para la resolución de su enigma personal en su primera obra En la Patagonia, su evolución como 
escritor hace difícil establecer si era un autor de libros de ficción o de viajes. El propio género, como se ha analizado a lo largo del presente artículo, comprende obras de tan diversa índole que la frontera no es de fácil delimitación. En el caso del escritor británico, se puede llegar a la conclusión de que en su penúltimo trabajo, Los trazos de la canción, recurrió a la forma narrativa más cercana a la ficción para diseccionar el desasosiego humano. Describió los paisajes y las gentes con las que se cruzó en su recorrido, pero, al mismo tiempo, indagó en el problema metafísico universal que le embargaba, es decir, el origen de la naturaleza viajera del hombre. Su peregrinaje por la tierra aborigen finalizó con un gran descubrimiento. La metáfora del viaje estaba en el corazón de toda narración. Esta idea daba sentido a toda su obra anterior, ya que se erigía en el reflejo de un viaje metafísico e indagación antropológica hacia el origen de su inquietud. Su periplo por Australia parecía el final de esa larga travesía en busca de la naturaleza viajera del hombre. Sin embargo, Utz, su último trabajo, anunció la primera etapa de un nuevo viaje literario. Hasta entonces había aprovechado las posibilidades que los distintos géneros literarios le ofrecían para alumbrar su propio estilo. Cuando partió hacia Patagonia tras el trozo de piel del brontosaurio, corría tras una idea. No había tiempo para detenerse en clasificaciones que entorpecieran la búsqueda de una respuesta. Llevó al lector a los territorios vírgenes de su imaginación. Se convirtió en el héroe que crecía como creador a medida que avanzaba en su viaje. Sus obras simbolizan, en este sentido, el sendero por el que todo ser humano transita hasta la llegada al paraíso. Su viaje literario le había convertido en un narrador de exploraciones íntimas. Localizó en el mapa el origen de la inquietud.

\section{REFERENCIAS}

Adams, P. G. 1983. Travel Literature and the Evolution of the Novel. University of Kentucky.

Baudelaire, C. P. 2010. Journaux Intimes. París: Livres Généraux.

Blaise, P. 1998. Pensamientos. Madrid: Ediciones Cátedra.

Blanton, C. 1997. Travel Writing: the self and the world. New York: Twayne Publishers.

Byron, R. 2001. Viaje a Oxiana. Barcelona: Ediciones Península.

Campbell, M. 1988. The Witness and the Other World: Exotic European Travel Writing, 400-1600. Ithaca: Cornell University Press.

Carmona Fernández, F. y Martínez Pérez, A. 1996. Libros de viaje en el mundo románico. Murcia: Universidad de Murcia.

Chatwin, B. 1993. Bruce Chatwin: Fotografias y cuadernos de viaje. Madrid: Anaya \& Mario Muchnik.

Chatwin, B. 1997. Anatomía de la inquietud. Madrid: Anaya \& Mario Muchnik.

Chatwin, B. 1997. En la Patagonia. Barcelona: Muchnik Editores.

Chatwin, B. 1997. Utz. Barcelona: Muchnik Editores.

Chatwin, B. 1988. Los trazos de la canción. Barcelona: Ediciones Península. 
Chatwin, B. 2001. El Virrey de Ouidah. Barcelona: Muchnik Editores.

Chatwin, B. 2002. Qué hago yo aquí. Barcelona: El Aleph.

Chatwin, B. 2003. Colina Negra. Barcelona: El Aleph.

Chatwin, B. y Theroux, P. (2001). Retorno a la Patagonia. Madrid: El taller de Mario Muchnik.

Chesterton, 2001. Robert Louis Stevenson. Valencia: Fundación ONCE.

Clapp, S. 1997. Con Bruce Chatwin. Barcelona: Muchnik Editores.

Cocker, M. 1992. Loneliness and Time. British Travel Writing in the Twentieth Century. London: Secker \& Warburg.

Douglas, N. 1924. Norton Book of Travel. Voyages and travels-Literary collections. Edited by Paul Fussell. New York: W. W. Norton \& Company Ltd.

Fussell, P. 1982. Abroad. British Literary Traveling Between the Wars. New York: Oxford University Press.

Greene, G. 2002. Journey Without Maps. London: Vintage.

Herodoto. 1996. Los nueve libros de la Historia. Madrid: Biblioteca Edaf.

Hudson, W. H. 1982. Far Away and Long Ago. London: Eland.

IGNATIEFF, M. 1987. An Interview with Bruce Chatwin. UK: Granta.

LABARge, M. W. 2000. Viajeros medievales. Hondarribia (Guipúzcoa): Editorial Nerea.

LAmB, J. 2000. Exploration and Exchange. Chicago: The University of Chicago Press.

LÉVI-Strauss, C. 1988. Tristes Trópicos. Barcelona: Ediciones Paidós Ibérica, S.A.

Meanor, P. 1996. Bruce Chatwin. New York: Twayne's English Authors Series.

Melville, H. 2001. Moby Dick. Barcelona: Editorial Debate.

Murray, N. 1993. Bruce Chatwin. Mid Glamorgan (Wales): Seren Books.

Reverte, J. 1998. Vagabundo en África. Madrid: Grupo Santillana de Ediciones.

Rimbaud, A. 1997. Prosas e iluminaciones. Barcelona: Ediciones 29.

RushDIE, S. 1991. Imaginary Homelands. NY: Granta Books.

Shakespeare, Ns. 1999. Bruce Chatwin. London: Harvill Press.

ShaKesPeAre, W. 1998. La tempestad. Madrid: Colección Austral. 